\title{
Different effects of anti-TNF-alpha biologic drugs on the small bowel macroscopic inflammation in patients with ankylosing spondylitis
}

\author{
A. CHITUL ${ }^{1}$, A.M. VOIOSU ${ }^{1,2}$, MĂDĂLINA MARINESCU ${ }^{2}$, SIMONA CARAIOLA $^{1,3}$, ADRIANA NICOLAU ${ }^{3}$, \\ GEORGETA CAMELIA BADEA ${ }^{1,3}$, MAGDA ILEANA PÂRVU ${ }^{4}$, R. A. IONESCU ${ }^{1,3}$, B. R. MATEESCU ${ }^{1,2}$, \\ M. R. VOIOSU ${ }^{1,2}$, C. R. BĂICUŞ ${ }^{1,3}$, M. RIMBAŞŞ, \\ ${ }^{1}$ Internal Medicine Department, "Carol Davila” University of Medicine, Bucharest, Romania \\ ${ }^{2}$ Gastroenterology Department, "Colentina” Clinical Hospital, Bucharest, Romania \\ ${ }^{3}$ Internal Medicine Department, "Colentina" Clinical Hospital, Bucharest, Romania \\ ${ }^{4}$ Rheumatology Department, "Colentina” Clinical Hospital, Bucharest, Romania
}

\begin{abstract}
Background \& Aims. Considering the ability of anti-TNF alpha drugs to lower the burden intestinal inflammation in patients with inflammatory bowel disease (IBD), and the similarity between IBD and ankylosing spondylitis (AS) regarding inflammatory intestinal involvement, we aimed to investigate the impact of anti-TNF alpha biologic therapy on subclinical intestinal inflammation in AS patients.

Methods. Between January 2008 and December 2013, 38 AS patients and 23 controls were enrolled in the study and investigated with small bowel videocapsule endoscopy examination and ileocolonoscopy. Each tertile of the small bowel (proximal, mid and distal) was assessed by calculating the Lewis score based on the image stream.

Results. The Lewis scores were significantly higher in the AS group compared to controls $(580.9 \pm 818$ vs. $81 \pm 121, \mathrm{p}<0.001) .16$ patients $(42.1 \%)$ were on anti-TNF alpha therapy (Adalimumab $(\mathrm{n}=5)$, Infliximab $(\mathrm{n}=5)$ or Etanercept $(\mathrm{n}=6)) .31 .3 \%$ of them used NSAIDs simultaneously, compared with $77.3 \%$ of the other patients $(\mathrm{p}<0.01)$. Their Lewis scores were lower compared to the other patients for the entire small bowel $(306 \pm 164 v s .790 \pm 1038, \mathrm{p}=0.015)$, its proximal and distal tertiles $(238 \pm 154$ vs. $560 \pm 543, \mathrm{p}=0.021$, and $140 \pm 189 v s .300 \pm 220$, $\mathrm{p}=0.027$, respectively). The Lewis score was also lower in patients receiving Adalimumab/ Infliximab compared to those on Etanercept for the entire bowel and its distal tertile (262 $\pm 165 \mathrm{vs}$. $380 \pm 148, \mathrm{p}=0.069$ and $62 \pm 101 v s .273 \pm 236, \mathrm{p}=0.060$, respectively).

Conclusion. Anti-TNF alpha therapy in patients with AS reduces the subclinical intestinal inflammation, but the magnitude seems to depend upon the class anti-TNF alpha agent used (Clinical Trials. gov NCT00768950).
\end{abstract}

Keywords: Ankylosing spondylitis, Anti-TNF alpha therapy, Lewis score, Videocapsule endoscopy, Nonsteroidal anti-inflammatory drugs.

\section{INTRODUCTION}

Ankylosing spondylitis (AS) is an autoimmune disease which primarily affects the joints or enthuses [1]. However, up to $70 \%$ of the patients are reported to have intestinal inflammation, mostly confined to the terminal ileum [2-4]. Consequent to the fact that tumor necrosis factor $\alpha$ is an integral component of the inflammatory cascade [5], antitumor necrosis factor alpha (TNF $\alpha$ ) agents represent an attractive therapeutical option for patients with inflammatory conditions such as AS and inflammatory bowel disease (IBD) [6]. In fact, the resemblance in intestinal inflammatory involvement between patients with ankylosing spondylitis and those with IBD gave rise to the supposition that anti-TNF $\alpha$ therapy can decrease the intestinal inflammation in AS patients as it does in IBD [7-10].

To complicate things further, while nonsteroidal anti-inflammatory drugs (NSAIDs) are considered to be the first-line treatment for symptomatic patients diagnosed with AS [11, 12], they frequently cause ulcerative lesions in the small bowel [13-16]. Furthermore, there is concern that NSAID therapy could aggravate the inflammatory bowel involvement in these patients [15], while recent experimental studies concluded that TNF alpha also plays a significant role in the pathogenesis of NSAID-induced bowel lesions [17].

Therefore, we hypothesized that patients with AS could benefit from anti-TNF alpha therapy, due to its effect on both the intestinal lesions occurring secondary to the disease (AS) itself and also NSAID-induced bowel injury. 


\section{MATERIAL AND METHODS}

This is a clinical prospective observational study performed between January 2008 and December 2013, in our tertiary referral academic hospital. During this period all consecutive adult patients diagnosed with ankylosing spondylitis (as defined by an Amor score $\geq 6$ and by the New York modified criteria), on stable doses of antirheumatic medications for at least 3 months, were screened for inclusion in the present study. The exclusion criteria were:

- negative result of the intestinal luminal patency test using the Agile capsule in patients with symptoms suggestive of intestinal stenosis or obstruction, history of abdominal or pelvic radiation therapy, or major abdominal surgery;

- swallowing disorders;

- cardiac pacemakers;

- a positive pregnancy test result or known pregnancy in evolution;

- lack of discernment;

- refusal to sign the informed consent.

The patients were investigated using small bowel (SB) videocapsule endoscopy examination (VCE) and ileocolonoscopy. SB-VCE examination was performed in all study patients by using a SB2 or SB2L PillCam (Given Imaging, Yokneam, Israel) - the latter with a battery lifetime of an hour longer than its previous version, after fasting for at least 12 hours and with 3 liters of bowel preparation solution (Endofalk, Dr. Falk Pharma $\mathrm{GmbH}$, Freiburg, Germany) administered prior to the videocapsule swallowing. $80 \mathrm{mg}$ of simethicone (Espumisan L solution, Berlin Chemie AG, Berlin, Germany) was administered orally 20 minutes before swallowing of the videocapsule. Fluids were allowed 2 hours after videocapsule ingestion, and a light meal 4 hours afterwards. The VCE recordings were evaluated with the RAPID ${ }^{\mathrm{TM}}$ software (versions 6 and 7, Given Imaging, Yokneam, Israel) by two reviewers (MR and MM) and the Lewis scores were computed using the dedicated software application by one of the investigators (MR). The Lewis scores were calculated for the entire small bowel, as well as separately for each of its tertiles (proximal, mid and distal, including besides the sub-scores for villous edema and ulcerative lesions, also the stenosis score on the concerned segment). Ileocolonoscopy was proposed to all study patients, but performed only in those who agreed to it, using an Olympus videocolonoscope (CF-Q160L, Olympus Optical Co. Ltd., Tokyo, Japan), under conscious sedation with midazolam (Dormicum $5 \mathrm{mg}$ vials, F. Hoffman-La Roche Ltd., Basel, Switzerland) administered intravenously using adjusted dosages. Demographic data and information about previous or concomitant medications were collected for all patients.

For the VCE examination, a control group consisting of subjects that were age and gender matched with the study population, without a condition predisposing to intestinal inflammation and with no concurrent NSAID intake in the previous 4 weeks was also enrolled along the duration of the present study and submitted to the same VCE examination protocol.

\section{Statistical analysis}

The gathered data were prospectively included into an electronic database. The statistical analysis of the data was performed using SPSS for Windows, version 16.0 (IBM Corp., Armonk, USA). For categorical variables the results were expressed as frequencies and percentages, and comparisons between groups were performed using Fisher's exact test. For continuous variables with normal distribution, the results were presented as means \pm standard deviation, and were furthermore analyzed with the Student's t test; for those with abnormal distribution, the results were expressed as median values, and analysis was performed with the MannWhitney $\mathrm{U}$ test. The hypothesis was bidirectional and a $\mathrm{p}$ value lower than 0.05 was considered statistically significant. The intra-rater reliability was assessed using the intraclass correlation coefficient [18].

\section{ETHICAL CONSIDERATIONS}

The study was conducted according to the Declaration of Helsinki, Good Clinical Practice (GCP) and local regulations. The protocol was approved by the institutional ethics committee and written informed consent was obtained from all enrolled patients prior to the study procedures. The study was registered on ClinicalTrials.gov with the number NCT00768950.

\section{RESULTS}

\section{The study groups}

38 patients with ankylosing spondylitis (22 males, $57.9 \%$ ), with a mean age of $38.6 \pm$ 10.9 years were enrolled in the study. The control group consisted of 23 subjects (11 males, $47.8 \%$ ), with a mean age of $42.9 \pm 9.9$ years $(p>0.05$ 
compared to the AS group). The indications for small bowel VCE examination for the subjects in the control group were: functional abdominal symptoms in 12 , obscure gastrointestinal bleeding in 4 , persistent halitosis in 1, postoperative reevaluation in 1 case of resected ileal neuroendocrine carcinoma, treated celiac disease in 1, PeutzJeghers polyposis in 1, transabdominal ultrasound description of a polyp in the terminal ileum (not confirmed) in 1 and presence of multiple colonic polyps in the other 2 .

\section{Intestinal inflammatory involvement}

The Lewis score could be computed in 37 of the 38 study patients. In one patient in whom the videocapsule did not reach the cecum the Lewis score could not be estimated; however, the presence of multiple inflammatory changes in the proximal part of the small bowel allowed estimation of the proximal tertile Lewis score of 1690 for that patient.

The mean value of the Lewis score in the study patients was $580.9 \pm 818$, while its median value was 337(range: 0-4846). Macroscopic intestinal inflammation, as defined by a Lewis score of more than 135 [19] was present in 33 of the 38 study patients $(86.8 \%)$.

24 patients $(63.3 \%)$ agreed to ileocolonoscopy performed as part of the present study on the same day as the VCE examination. Of them, only 4 patients $(16.7 \%$ of those performing ileocolonoscopy) had macroscopic signs of inflammation at the level of the terminal ileum.

\section{Anti TNF-alpha therapy}

Of the 38 patients with ankylosing spondylitis, $16(42.1 \%)$ were on anti-TNF alpha biologic therapy: 5on Adalimumab (Humira ${ }^{\circledR}$, AbbVie Ltd, Maidenhead, United Kingdom) - all at a dose of $40 \mathrm{mg}$ subcutaneously every 2 weeks, 5 on Infliximab (Remicade ${ }^{\circledR}$, Janssen Biologics B.V., Leiden, Netherlands) at a dose of $5 \mathrm{mg} / \mathrm{kgc}$ in continuous intravenous perfusion every 8 weeks, and 6 on Etanercept (Enbrel®, Pfizer Limited, Kent, United Kingdom) all at a dose of $50 \mathrm{mg}$ administered subcutaneously weekly. Their mean age was $41.3 \pm 11.2$ years, compared to $36.7 \pm 10.6$ in those not receiving biologic compounds $(\mathrm{p}=0.25)$.

The use of anti-TNF-alpha drugs was associated with a statistically significant reduction in the small bowel inflammation score unveiled by the endoscopic video capsule examination in our study group. The difference in inflammation was significant for the global assessment of the small bowel (mean of Lewis scores of $306 \pm 164$ vs. $790 \pm 1038, p=$ 0.015 ), and also at the level of its proximal and distal tertiles (mean of partial Lewis scores of $238 \pm 154$ vs. $560 \pm 543$, and $140 \pm 189$ vs. $300 \pm$ 220 , respectively, with $p$ values of 0.021 and 0.027 , respectively), but not at the level of the mid tertile (mean of partial Lewis scores of $132 \pm 143 v s .207 \pm$ $184, p=0.32)$ (Figure 1).

Both groups of patients with AS, with and without biological treatment, presented significantly higher Lewis scores when compared with the control group $(p<0.05)$ at all levels of the small bowel (mean of Lewis scores of $81 \pm 121,32 \pm 65$, $29 \pm 57$, and $47 \pm 115$ for the bowel as a whole, its proximal, mid and distal tertiles in the control group, respectively).

Of the 4 patients with macroscopic signs of inflammation at the level of the terminal ileum unveiled by ileocolonoscopy, 2 had anti-TNF alpha biologic therapy (one Etanercept and the other one Adalimumab) and $2 \operatorname{did} \operatorname{not}(\mathrm{p}=0.57)$.

\section{NSAID treatment}

Of the 16 patients with anti TNF-alpha biologic therapy, only 5 (31.3\%) had concomitant NSAIDs, while of the remaining 22 patients, 17 $(77.3 \%)$ concomitantly took at least one NSAID $(\mathrm{p}<0.01)$ (Figure 2).

\section{Type of anti-TNF alpha therapy}

The type of anti-TNF alpha agent influenced the degree of endoscopic inflammatory burden. The Lewis score was found to be much lower for the bowel as a whole $(262 \pm 165$ vs. $380 \pm 148$, $\mathrm{p}=0.069)$ and also for its distal tertile $(62 \pm 101 v s$. $273 \pm 236, \mathrm{p}=0.060)$ in patients receiving Adalimumab or Infliximab in comparison with those receiving Etanercept. Not as obvious were the differences for its proximal ( $227 \pm 195$ vs. $257 \pm 39$, $\mathrm{p}=0.22)$ and mid tertiles $(129 \pm 146 v s .138 \pm 152$, $\mathrm{p}=0.82$ ) (Figure 3).

22 patients had concomitantly taken an NSAID. Of them, those who were on anti-TNF alpha treatment had lower Lewis scores $(413 \pm 207$ vs. $573 \pm 480$ ), but the difference was not statistically significant $(\mathrm{p}=0.72)$. Of the 5 patients who received both an anti-TNF alpha agent and an NSAID drug, 2 were on Adalimumab, 2 on Infliximab and 1 on Etanercept. 

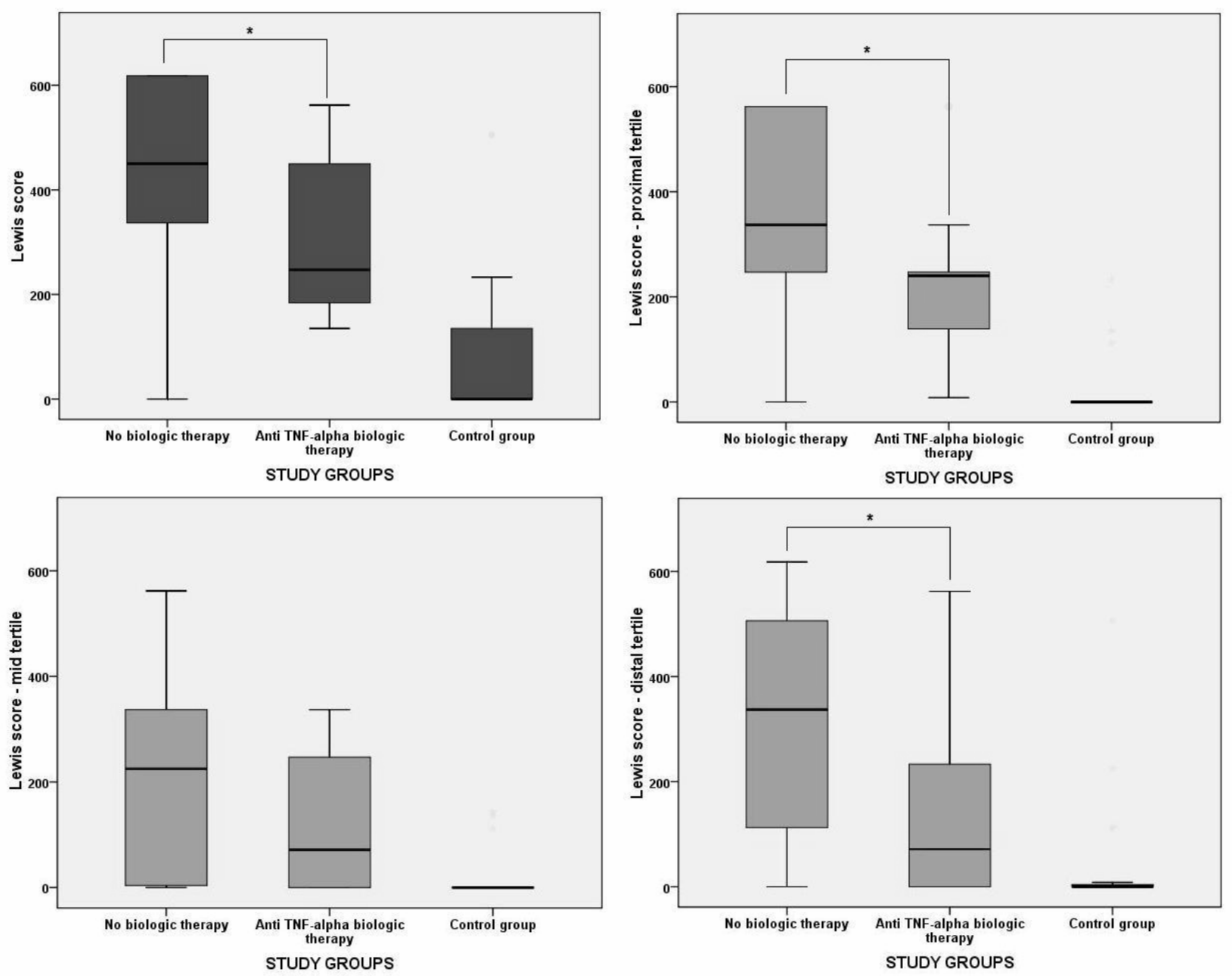

Figure 1. Graphic representation of the comparisons between the Lewis scores at the level of whole small bowel and its proximal, mid and distal tertiles in patients with and without biologic treatment $v s$. the controls ( ${ }^{*}$, statistically significant).

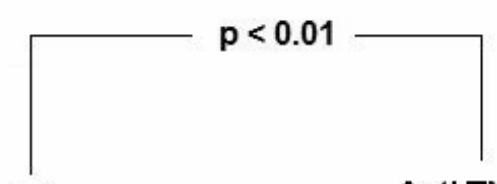

No biologic therapy

Anti TNF-alpha

biologic therapy

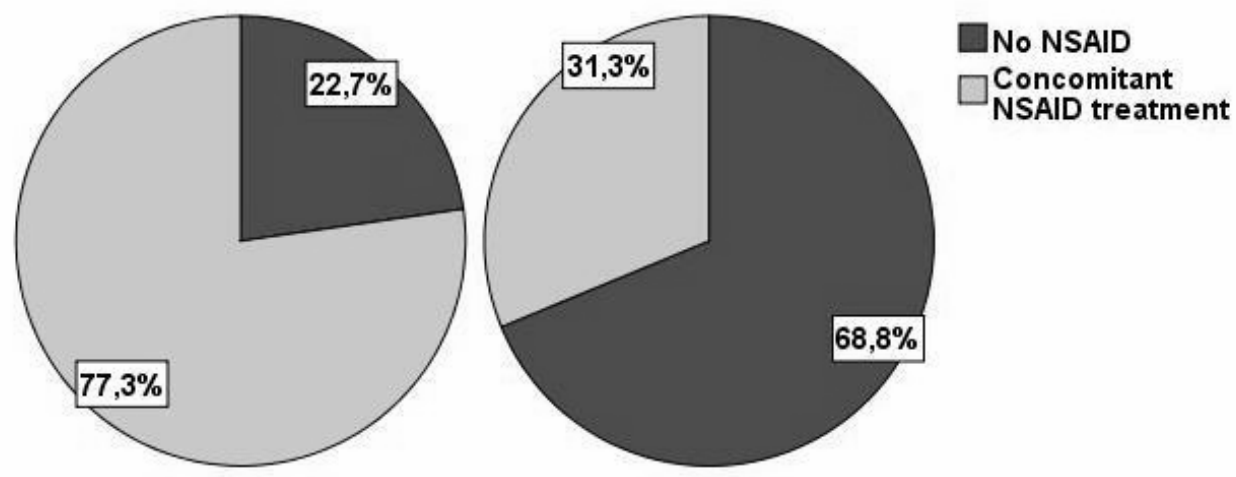

Figure 2. Comparison between the groups of anti-TNF alpha treatment regarding their non-steroidal antiinflammatory drugs (NSAIDs) consumption. 

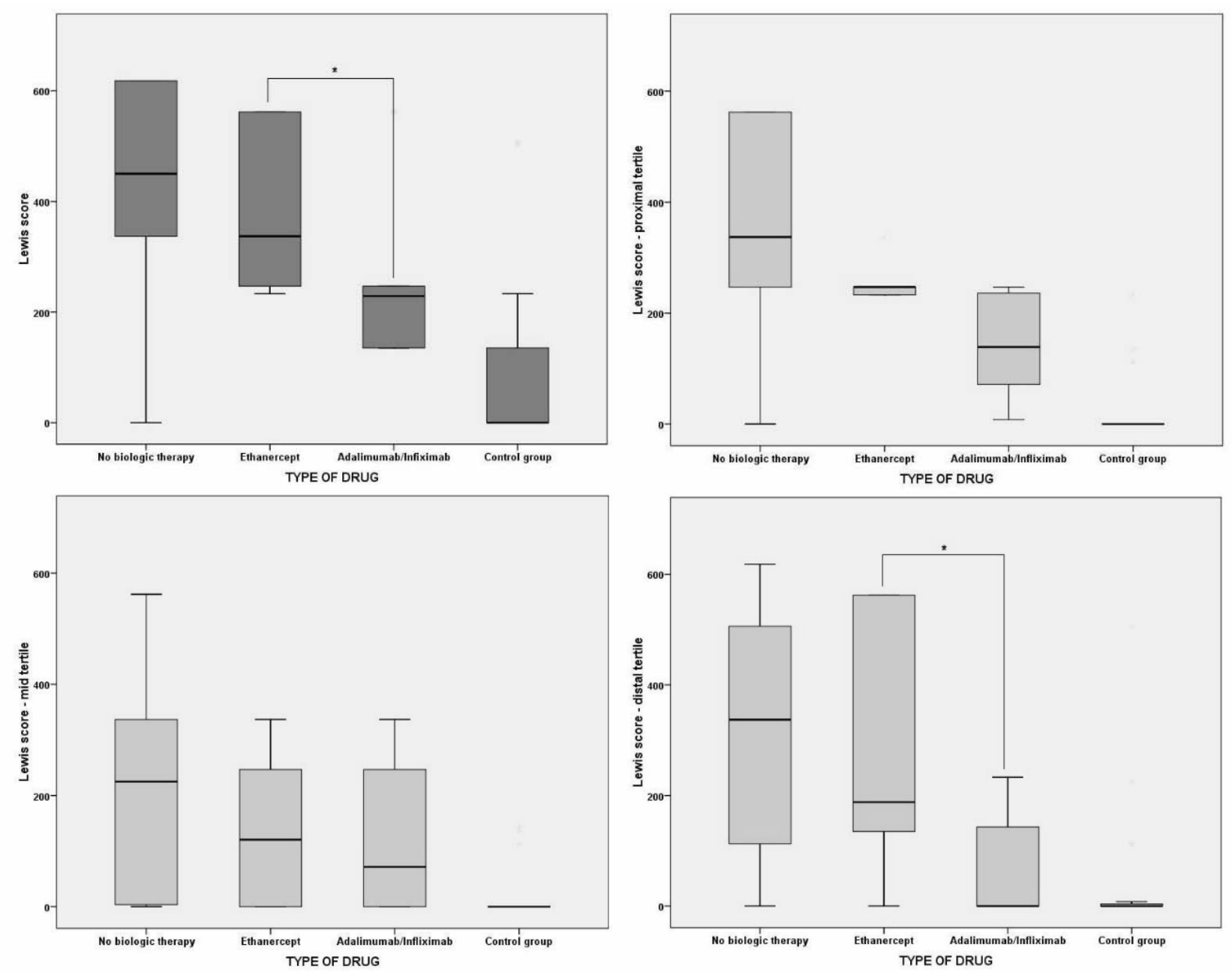

Figure 3. Graphic representation of the comparisons between the Lewis scores in the study patients with and without treatment with biological therapy (Adalimumab/Infliximab, vs. Etanercept), and the control group, at the level of whole small bowel and its proximal, mid and distal tertiles (*, statistically significant).

\section{Intra-rater reliability}

The intra-observer reliability of the Lewis scores was assessed in 10 patients. The intraclass correlation coefficient [18] was 0.945 (95\% CI, $0.792-0.986$ ), indicating very good agreement between the two evaluations.

\section{DISCUSSION}

The main finding of our pilot study is that anti-TNF-alpha biologic therapy in patients with ankylosing spondylitis seems to significantly reduce macroscopic inflammatory activity in the bowel as assessed by videocapsule endoscopy. The intestinal inflammation diminishes markedly, in some segments of the bowel even close to the level of the controls. However, this reduction in intestinal inflammation is paralleled by a reduction in NSAID consumption.
Studies have shown that up to two thirds of AS patients harbor intestinal inflammatory lesions $[2,18,20,21]$ and that these chronic inflammatory bowel involvements are histopathologically similar to Crohn's disease (CD) -mucosal glandular structure is disorganized due to crypts destruction, irregular and fused villi, and lamina propria includes a mononuclear infiltrate. As such, current data (clinical, genetic, histopathologic and immunologic) suggests that AS and CD should be acknowledged as two different phenotypes of a common underlying immune-mediated inflammatory disease pathway [22], especially seeing that $5-13 \%$ of AS patients go on to develop IBD $[23,24]$. AS could thus serve as a model for subclinical Crohn's disease.

We hypothesized that the therapeutical intervention used to decrease inflammatory burden in IBD patients would have a similar beneficial effect on AS patients with inflammatory bowel involvement. Anti-TNF alpha agents have become an 
essential therapeutical alternative in the treatment of both rheumatologic disorders and IBD [6, 25], and according to our study the usage of biological therapy was associated with a lower inflammation score for the small bowel, as assessed by the endoscopic video capsule examination.

However, there are at least two different types of anti-TNF alpha drugs available. Adalimumab and Infliximab target transmembrane TNF alpha, which is highly expressed by the lamina propria T-lymphocytes, therefore blocking the transmembrane signaling pathway and inducing apoptosis of the activated T-lymphocytes [26]. Etanercept is a soluble TNF receptor with a different mechanism of action and also a different pharmacokinetic than the above mentioned anti TNF alpha antibodies [27, 28]. Adalimumab and Infliximab are routinely used in both IBD and AS, while Etanercept has not been found to have an effect in Crohn's disease or ulcerative colitis and is not licensed for this use. Indeed, in a report on two patients with spondyloarthritis and Crohn's disease that received treatment with Etanercept, an excellent response was noticeable regarding the articular involvement, but persistence or even an exacerbation of Crohn's symptoms was observed [29]. Therefore, for all the above reasons, Etanercept seems different from Adalimumab and Infliximab in its mechanism of action on the gut, although there are no obvious clinical differences for the articular effect of the drug [30-32]. However, no controlled study was conducted to study the effect on the subclinical gut inflammation in spondyloarthritis patients of the previously mentioned anti-TNF alpha drugs. But given the lack of benefit of Etanercept on intestinal inflammatory involvement in the present study, our results seem to confirm the findings of a 2007 meta-analysis, proving that AS patients on Etanercept develop more frequently overt IBD during treatment, similarly to placebo, compared to those on Adalimumab or Infliximab [33].

A potential confounding factor we accounted for was the simultaneous use of NSAID agents, a mainstay of treatment strategies in rheumatologic disorders. This complicated our investigation but offered a chance to look into the impact of antiTNF alpha agents on NSAID use and their intestinal side effects. Supporting the role of NSAIDs in fueling the smoldering inflammatory intestinal activity in AS is the association with inflammatory changes, such as erythema, erosions, ulcers, and also strictures and perforations $[14,20]$ reported in healthy controls. In fact, up to two thirds of NSAID users present inflammatory small bowel mucosal changes or an increase in intestinal permeability $[11,16]$, and, surprisingly, up to the same two thirds of AS patients are previously described to harbor intestinal inflammatory lesions $[2,18,20$, 21]. Thus, the issue of intestinal inflammation in spondyloarthritides is very complex, and no one proved so far what is the real contribution of NSAIDs to its development and maintenance

Because NSAID therapy is currently considered to be the first-line therapy of AS [34], it has been difficult to isolate their effect on intestinal inflammation in this setting [35-37]. Appleyard et al. proved in an experimental study that TNF alpha plays a pivotal role in the pathogenesis of intestinal injuries induced by NSAIDs [17]. Knowing that NSAID treatment has the potential to enhance the bowel inflammation in AS patients [11, 14, 16, 20], we speculated that these patients could benefit from anti-TNF alpha therapy both for lowering ASrelated intestinal injuries as well as for the NSAIDinduced lesions. Similar to our findings, recent studies have shown that rheumatoid arthritis patients who received anti-TNF agents had less severe NSAID-induced enteropathy in comparison to those who did not receive such therapy, supporting the protective effect of anti-TNF alpha agents against NSAID-induced gut lesions [12].

Our study also has several limitations. While a larger sample size is always welcome, a major issue of any investigation in this population is the confounding effect of the reduced NSAID use in patients on anti-TNF alpha agents. Thus, in future studies all enrolled AS patients should have their NSAIDs withheld for at least 2 weeks (if not more) in order to isolate the impact of anti-TNF alpha on intestinal inflammation, while researchers should focus on elucidating the role of NSAIDs on triggering and maintaining the intestinal inflammation in spondyloarthritides. This would help in identifying if early intervention with biological therapies results in a better outcome for the intestinal involvement on the long term in patients with AS.

In conclusion, in this study settlement, given the above limitations about the NSAID concomitant consumption, we have found that anti-TNF-alpha biological treatments act for reducing the level of the small bowel macroscopic inflammation, as assessed by videocapsule examination. Also, in this cohort there was a significant difference in effect 
between the major classes of anti-TNF alpha agents used, regardless of NSAID therapy.

Acknowledgment. This paper has been supported by the CNCSIS-UEFISCSU, Romanian Ministry of Education and Research, project number PNII-IDEI 320/2007.
Declaration of interest. All the authors have no conflict of interests to disclose regarding this paper.

Disclosure. The results of the present study have also been presented at UEG Week 2013 as oral presentation, and at the $33^{\text {rd }}$ National Congress of Gastroenterology 2013 as poster.

Scopuri şi obiective. Având în vedere abilitatea agenților anti-TNF alfa de a diminua inflamația intestinală în rândul pacienților cu boli inflamatorii intestinale, precum şi similitudinea afectării inflamatorii intestinale din cadrul acestor boli cu cea din spondilita anchilozantă, ne-am propus să investigăm efectul terapiei biologice anti-TNF alfa asupra inflamației intestinale subclinice la bolnavii cu spondilită anchilozantă.

Metode. In perioada ianuarie 2008 - decembrie 2013, au fost incluşi în studiu 38 de pacienți cu spondilită anchilozantă şi 23 de persoane ce au reprezentat lotul martor. Aceştia au fost investigați prin examinarea intestinului subțire cu videocapsula endoscopică şi prin ileocolonoscopie. Fiecare treime (proximală, mijlocie şi distală) a intestinului subțire a fost evaluată cu ajutorul scorului Lewis calculat pe baza imaginilor furnizate de examinarea cu videocapsula.

Rezultate. Scorul Lewis a fost semnificativ mai ridicat în rândul celor cu spondilită față de lotul martor (580.9 \pm 818 vs. $81 \pm 121, p<0.001)$. 16 pacienți $(42,1 \%)$ erau sub tratament cu agenți biologici inhibitori ai TNF alfa [Adalimumab $(n=5)$, Infliximab $(n=5)$, Etanercept $(n=6)]$. 31,3\% dintre aceştia primeau simultan şi antiinflamatorii nonsteroidiene, in timp ce 77,3\% dintre ceilalți pacienți utilizau cel puțin un antiinflamator nonsteroidian $(p<0.01)$. Scorul Lewis în rândul celor ce primeau terapie anti-TNF alfa a fost mai mic față de ceilalți pacienți, atât per ansamblu (306 \pm 164 vs. $790 \pm 1038, p=0.015)$, cât şi la nivelul treimii proximale şi distale $(238 \pm 154 v s .560 \pm 543, p=0.021$, şi respectiv $140 \pm$ 189 vs. $300 \pm 220, p=0.027)$. Scorul a fost mai redus şi la cei ce foloseau Adalimumab/Infliximab în comparație cu cei ce primeau Etanercept, la nivelul intregului intestin cât şi în segmentul distal (262 \pm 165 vs. $380 \pm 148, p=0.069$ şi respectiv $62 \pm 101$ vs. $273 \pm 236, p=0.060)$.

Concluzie. Terapia anti-TNF alfa la pacienții cu spondilită anchilozantă reduce inflamația intestinală subclinică, această diminuare variind în funcție de agentul utilizat (Clinical Trials. gov NCT00768950).

Correspondence to: Mihai Rimbaş MD, PhD, Gastroenterology Department,

"Colentina" Clinical Hospital, 19-21 Ştefan cel Mare Street, 020125, Bucharest, Romania

Tel: +40 723232052, Fax: +40 318162376

E-mail:mrimbas@gmail.com

\section{ABBREVIATIONS}

Ankylosing spondylitis (AS)

Inflammatory bowel disease (IBD)

Tumor necrosis factor alpha (TNF $\alpha$ )

Nonsteroidal anti-inflammatory drugs (NSAIDs)

Small bowel (SB)

Videocapsule endoscopy examination (VCE)

Crohn's disease (CD) 


\section{REFERENCES}

1. CIUREA A., SCHERER A., EXER P., BERNHARD J., DUDLER J., BEYELER B., et al. Tumor necrosis factor alpha inhibition in radiographic and nonradiographic axial spondyloarthritis: results from a large observational cohort. Arthritis Rheum. 2013; 65(12):3096-106.

2. LEIRISALO-REPO M., TURUNEN U., STENMAN S., HELENIUS P., SEPPALA K. High frequency of silent inflammatory bowel disease in spondylarthropathy. Arthritis Rheum. 1994; 37(1):23-31.

3. DE KEYSER F., MIELANTS H. The gut in ankylosing spondylitis and other spondyloarthropathies: inflammation beneath the surface. J Rheumatol. 2003; 30(11):2306-7.

4. DE KEYSER F., ELEWAUT D., DE VOS M., DE VLAM K., CUVELIER C., MIELANTS H., et al. Bowel inflammation and the spondyloarthropathies. Rheum Dis Clin North Am. 1998; 24(4):785-813, ix-x.

5. BRADLEY J.R. TNF-mediated inflammatory disease. The Journal of Pathology. 2008; 214(2):149-60.

6. BRAUN J., SIEPER J. Overview of the use of the anti-TNF agent infliximab in chronic inflammatory diseases. Expert Opin Biol Ther. 2003; 3(1):141-68.

7. VAN DULLEMEN H.M., VAN DEVENTER S.J., HOMMES D.W., BIJL H.A., JANSEN J., TYTGAT G.N., et al. Treatment of Crohn's disease with anti-tumor necrosis factor chimeric monoclonal antibody (cA2). Gastroenterology. 1995; 109(1):129-35.

8. D'HAENS G., VAN DEVENTER S., VAN HOGEZAND R., CHALMERS D., KOTHE C., BAERT F., et al. Endoscopic and histological healing with infliximab anti-tumor necrosis factor antibodies in Crohn's disease: A European multicenter trial. Gastroenterology. 1999; 116(5):1029-34.

9. FORD A.C., SANDBORN W.J., KHAN K.J., HANAUER S.B., TALLEY N.J., MOAYYEDI P. Efficacy of biological therapies in inflammatory bowel disease: systematic review and meta-analysis. Am J Gastroenterol. 2011; 106(4):644-59, quiz 60.

10. JARNEROT G., HERTERVIG E., FRIIS-LIBY I., BLOMQUIST L., KARLEN P., GRANNO C., et al. Infliximab as rescue therapy in severe to moderately severe ulcerative colitis: a randomized, placebo-controlled study. Gastroenterology. 2005; 128(7):1805-11.

11. SONG I.H., PODDUBNYY D.A., RUDWALEIT M., SIEPER J. Benefits and risks of ankylosing spondylitis treatment with nonsteroidal antiinflammatory drugs. Arthritis Rheum. 2008; 58(4):929-38.

12. WATANABE T., TANIGAWA T., SHIBA M., NADATANI Y., NAGAMI Y., SUGIMORI S., et al. Anti-tumour necrosis factor agents reduce non-steroidal anti-inflammatory drug-induced small bowel injury in rheumatoid arthritis patients. Gut. 2014; 63(3):409-14.

13. MAIDEN L., THJODLEIFSSON B., THEODORS A., GONZALEZ J., BJARNASON I. A quantitative analysis of NSAIDinduced small bowel pathology by capsule enteroscopy. Gastroenterology. 2005; 128(5):1172-8.

14. WATANABE T., TANIGAWA T., NADATANI Y., OTANI K., MACHIDA H., OKAZAKI H., et al. Mitochondrial disorders in NSAIDs-induced small bowel injury. J Clin Biochem Nutr. 2011; 48(2):117-21.

15. BABB R.R. Gastrointestinal complications of nonsteroidal anti-inflammatory drugs. West J Med. 1992; 157(4):444-7.

16. SIGTHORSSON G., TIBBLE J., HAYLLAR J., MENZIES I., MACPHERSON A., MOOTS R., et al. Intestinal permeability and inflammation in patients on NSAIDs. Gut. 1998; 43(4):506-11.

17. APPLEYARD C.B., MCCAFFERTY D.M., TIGLEY A.W., SWAIN M.G., WALLACE J.L. Tumor necrosis factor mediation of NSAID-induced gastric damage: role of leukocyte adherence. Am J Physiol. 1996; $270(1$ Pt 1):G42-8.

18. CICCIA F., RIZZO A., TRIOLO G. Subclinical gut inflammation in ankylosing spondylitis. Curr Opin Rheumatol. 2016; 28(1):89-96.

19. GRALNEK I.M., DEFRANCHIS R., SEIDMAN E., LEIGHTON J.A., LEGNANI P., LEWIS B.S. Development of a capsule endoscopy scoring index for small bowel mucosal inflammatory change. Aliment Pharmacol Ther. 2008; 27(2):146-54.

20. ORLANDO A., RENNA S., PERRICONE G., COTTONE M. Gastrointestinal lesions associated with spondyloarthropathies. World J Gastroenterol. 2009; 15(20):2443-8.

21. DE KEYSER F., BAETEN D., VAN DEN BOSCH F., DE VOS M., CUVELIER C., MIELANTS H., et al. Gut inflammation and spondyloarthropathies. Curr Rheumatol Rep. 2002; 4(6):525-32.

22. MIELANTS H., DE KEYSER F., BAETEN D., VAN DEN BOSCH F. Gut inflammation in the spondyloarthropathies. Curr Rheumatol Rep. 2005; 7(3):188-94.

23. ELEWAUT D. Linking Crohn's Disease and Ankylosing Spondylitis: It's All about Genes! PLoS Genet. 2010; 6(12).

24. RUDWALEIT M., BAETEN D. Ankylosing spondylitis and bowel disease. Best Pract Res Clin Rheumatol. 2006; $20(3): 451-71$.

25. SENABRE-GALlEGO JÉ M., SANTOS-RAMÍREZ C., SANTOS-SOLER G., SALAS-HEREDIA E., SÁNCHEZBARRIOLUENGO M., BARBER X., et al. Long-term safety and efficacy of etanercept in the treatment of ankylosing spondylitis. Patient Prefer Adherence. 2013; 7:961-72.

26. VAN DEVENTER S.J. Transmembrane TNF-alpha, induction of apoptosis, and the efficacy of TNF-targeting therapies in Crohn's disease. Gastroenterology. 2001; 121(5):1242-6.

27. GOLAN D.E., TASHJIAN A.H. Principles of pharmacology : the pathophysiologic basis of drug therapy. Philadelphia: Wolters Kluwer Health/Lippincott Williams \& Wilkins; 2012.

28. VAN DEN BRANDE J.M.H., BRAAT H., VAN DEN BRINK G.R., VERSTEEG H.H., BAUER C.A., HOEDEMAEKER I., et al. Infliximab but not etanercept induces apoptosis in lamina propria T-lymphocytes from patients with Crohn's disease. Gastroenterology. 2003; 124(7):1774-85.

29. MARZO-ORTEGA H., MCGONAGLE D., O'CONNOR P., EMERY P. Efficacy of etanercept for treatment of Crohn's related spondyloarthritis but not colitis. Ann Rheum Dis. 2003; 62(1):74-6. 
30. KRUITHOF E., DE RYCKE L., ROTH J., MIELANTS H., VAN DEN BOSCH F., DE KEYSER F., et al. Immunomodulatory effects of etanercept on peripheral joint synovitis in the spondylarthropathies. Arthritis Rheum. 2005; 52(12):3898-909.

31. VAN DER HEIJDE D., DIJKMANS B., GEUSENS P., SIEPER J., DEWOODY K., WILLIAMSON P., et al. Efficacy and safety of infliximab in patients with ankylosing spondylitis: results of a randomized, placebo-controlled trial (ASSERT). Arthritis Rheum. 2005; 52(2):582-91.

32. KRUITHOF E., BAETEN D., VAN DEN BOSCH F., MIELANTS H., VEYS E.M., DE KEYSER F. Histological evidence that infliximab treatment leads to downregulation of inflammation and tissue remodelling of the synovial membrane in spondyloarthropathy. Ann Rheum Dis. 2005; 64(4):529-36.

33. BRAUN J., BARALIAKOS X., LISTING J., DAVIS J., VAN DER HEIJDE D., HAIBEL H., et al. Differences in the incidence of flares or new onset of inflammatory bowel diseases in patients with ankylosing spondylitis exposed to therapy with anti-tumor necrosis factor alpha agents. Arthritis Rheum. 2007; 57(4):639-47.

34. PODDUBNYY D. Axial spondyloarthritis: is there a treatment of choice? Ther Adv Musculoskelet Dis. 2013; 5(1):45-54.

35. MIELANTS H., VEYS E.M., DE VOS M., CUVELIER C., GOEMAERE S., DE CLERCQ L., et al. The evolution of spondyloarthropathies in relation to gut histology. I. Clinical aspects. J Rheumatol. 1995; 22(12):2266-72.

36. MIELANTS H., VEYS E.M., CUVELIER C., DE VOS M., GOEMAERE S., DE CLERCQ L., et al. The evolution of spondyloarthropathies in relation to gut histology. III. Relation between gut and joint. J Rheumatol. 1995; 22(12):2279-84.

37. MIELANTS H., VEYS E.M., CUVELIER C., DE VOS M., GOEMAERE S., DE CLERCQ L., et al. The evolution of spondyloarthropathies in relation to gut histology. II. Histological aspects. J Rheumatol. 1995; 22(12):2273-8.

Received November 1, 2016 